\title{
The mode of action of low molecular weight heparin preparation (PK10169) and two of its major components on thrombin generation in plasma
}

Citation for published version (APA):

Beguin, S., Mardiguian, J., Lindhout, T., \& Hemker, H. C. (1989). The mode of action of low molecular weight heparin preparation (PK10169) and two of its major components on thrombin generation in plasma. Thrombosis and Haemostasis, 61(1), 30-34. https://doi.org/10.1055/s-0038-1646522

Document status and date:

Published: 01/01/1989

DOI:

10.1055/s-0038-1646522

Document Version:

Publisher's PDF, also known as Version of record

Please check the document version of this publication:

- A submitted manuscript is the version of the article upon submission and before peer-review. There can be important differences between the submitted version and the official published version of record.

People interested in the research are advised to contact the author for the final version of the publication, or visit the DOI to the publisher's website.

- The final author version and the galley proof are versions of the publication after peer review.

- The final published version features the final layout of the paper including the volume, issue and page numbers.

Link to publication

\footnotetext{
General rights rights.

- You may freely distribute the URL identifying the publication in the public portal. please follow below link for the End User Agreement:

www.umlib.nl/taverne-license

Take down policy

If you believe that this document breaches copyright please contact us at:

repository@maastrichtuniversity.nl

providing details and we will investigate your claim.
}

Copyright and moral rights for the publications made accessible in the public portal are retained by the authors and/or other copyright owners and it is a condition of accessing publications that users recognise and abide by the legal requirements associated with these

- Users may download and print one copy of any publication from the public portal for the purpose of private study or research.

- You may not further distribute the material or use it for any profit-making activity or commercial gain

If the publication is distributed under the terms of Article $25 \mathrm{fa}$ of the Dutch Copyright Act, indicated by the "Taverne" license above, 


\title{
The Mode of Action of Low Molecular Weight Heparin Preparation (PK10169) and Two of its Major Components on Thrombin Generation in Plasma
}

\author{
S. Béguin, J. Mardiguian*, T. Lindhout, and H. C. Hemker \\ From the Dept. of Biochemistry, University of Limburg, Maastricht, The Netherlands, \\ and the Rhône Poulenc Santé*, Gennevilliers, France
}

\section{Key words}

Low molecular weight heparin - Thrombin - Prothrombin activation

\section{Summary}

We studied the mode of action of the low molecular weight heparin PK10169 and two of its constituent fractions: EMT 966 High Molecular Weight Fraction and EMT 967 Low Molecular Weight Fraction.

EMT 966 like standard heparin, acts primarily on thrombin formed and not on prothrombinase (S type heparin). In contrast EMT 967 has no direct effect on thrombin. At high concentrations, it inhibits the prothrombinase complex ( $\mathrm{P}$ type heparin). PK10169, that contains the two EMTs shows both activities: antithrombin and antiprothrombinase (mixed type heparin).

The addition of increasing amounts of EMT 967 to a constant amount of EMT 966 does not influence the breakdown constant of endogenous thrombin which is determined by the concentration of EMT 966 only. This demonstrates the absence of competition for AT III between the two components of PK10169.

In platelet rich plasma, EMT 966 inhibits and postpones thrombin generation more efficiently than unfractionated heparin, probably because it is less sensitive to neutralization by platelet components (platelet factor 4). Amounts of EMT 967 that hardly inhibit thrombin generation in platelet rich plasma enhance the effect of EMT 966 probably by neutralizing platelet factor 4 .

\section{Introduction}

Recently we developed a method that enables us to estimate the course of prothrombinase activity in clotting plasma (1). This method allowed us to discern the existence of two different types of heparin according to their different modes of action on thrombin generation in plasma $(2,3)$. The $S$ type heparins that, like standard heparin, act mainly by thrombin scavenging and the P type heparins that, like the AT III binding pentasaccharide ( 2 , 3) are inactive towards thrombin but inhibit prothrombinase in plasma. From preliminary experiments it appeared that PK10169 was neither an $\mathrm{S}$ or an $\mathrm{P}$ heparin, but showed intermediate behaviour. It thus imported to know if this was due to an intrinsic property of one species of heparin molecule or due to PK10169 being a mixture of $\mathrm{S}$ and $\mathrm{P}$ type heparins.

Furthermore, in platelet rich plasma (PRP) some heparins are more susceptible to neutralization by platelet factor 4 than others.

Correspondence to: Dr. H. C. Hemker, Dept. of Biochemistry, University of Limburg, P.O. Box 616, $6200 \mathrm{MD}$ Maastricht, The Netherlands
Again, we wanted to investigate whether a poorly active heparin fraction could influence the action of an active fraction via platelet factor 4 neutralization.

\section{Materials and Methods}

\section{Materials}

The chromogenic substrate for thrombin was H.D-Phe-Pip-Arg-pNA (S2238) from KABI, Sweden. Kaolin was "Kaolin léger" provided by B. L. B. Laboratoires du Bois de Boulogne (Putcaux-France). The heparins were supplied by Pharmuka Laboratories (France). PK10169 is obtained by alkaline hydrolysis of the benzylic ester of heparin. According to the manufacturer PK10169 is identical to the commercially available Enoxaparin/Lovenox ${ }^{\circledR}$. EMT 966 and EMT 967 are prepared by gcl filtration of PK10169 on ultrogel AcA206 roughly one third of PK 10169 was in the EM 967 fraction and two thirds in EMT 966. The 4th International Standard for Heparin(4th I.S.H.) was from the National Institute for Biological Standards and Control. The average molecular weight, antifactor $\mathrm{II}_{\mathrm{a}}$ and antifactor $\mathrm{X}_{\mathrm{a}}$ activities, given by the manufacturers are indicated in Table 1. These activities were measured as described in Vinazzer and Woler (4).

\section{Plasma}

Blood from healthy donors was collected on $0.13 \mathrm{M}$ trisodium citrate; nine parts of blood to one part of citrate solution. A first and a second centrifugation were performed at $3,000 \times \mathrm{g}$, at $15^{\circ} \mathrm{C}$ for 15 minutes. A third centrifugation was done at $4^{\circ} \mathrm{C}$, for 1 hour at $23,000 \times \mathrm{g}$. The platelet free plasma thus obtained was stored at $-80^{\circ} \mathrm{C}$. It was checked that the clotting factors and the antiproteases were in the normal range.

Defibrinated plasma was obtained by mixing an aliquot of plasma with $1: 50$ volume of a reptilase solution, letting a clot form for $10 \mathrm{~min}$ at $37^{\circ} \mathrm{C}$ and keeping the clotted plasma at $0^{\circ} \mathrm{C}$ for $10 \mathrm{~min}$. The fibrin formed was discarded by centrifugation $\left(10 \mathrm{~min}, 5,000 \times \mathrm{g}, 4^{\circ} \mathrm{C}\right)$ or by winding it on a small plastic spatula. The concentration of factors II, VII, VIII, IX, X, XI and XII did not significantly change by the reptilase treatment as has been shown before (1).

\section{Proteins}

Reptilase was obtained from Laboratoires Stago (Asnières, France), a solution was obtained according to the instructions of the manufacturer. Soybean trypsin inhibitor (batch No. 43 F-800) was obtained from Sigma (St. Louis, USA). Staphylocoagulase was obtained from Laboratoires Stago (Asnières, France) and prepared according to the instructions of the manufacturer. Coagulation factors were purified as indicated in Béguin et al. (3). Human AT III was prepared by polyethylene glycol precipitation and heparin-scpharose affinity chromatography (5) followed by ionexchange chromatography to remove the heparin (6).

\section{Determination of Prothrombinase Activity in Plasma}

To $200 \mu \mathrm{l}$ of defibrinated plasma is added $50 \mu \mathrm{l}$ of $0.05 \mathrm{M}$ Tris- $\mathrm{HCl}$, $0.1 \mathrm{M} \mathrm{NaCl}, 0.5 \mathrm{mg} / \mathrm{ml}$ ovalbumin, $\mathrm{pH} 7.35$ containing heparin at the desired concentration and incubated for $5 \mathrm{~min}$ at $37^{\circ} \mathrm{C}$. At zero time, thrombin generation is started by the addition of $50 \mu$ l of a solution 
containing $100 \mathrm{mM}$ of $\mathrm{CaCl}_{2}$ and a trigger of coagulation. For the extrinsic system this is human brain thromboplastin, final dilution $1: 240$, for the intrinsic system $1 \mu \mathrm{M}$ phospholipid and $0.25 \mathrm{mg}$ kaolin (final concentrations). At intervals a $10 \mu \mathrm{I}$ aliquot of the mixture is sampled into a disposable plastic cuvette containing $0.465 \mu \mathrm{l}$ of $0.05 \mathrm{M}$ Tris- $\mathrm{HCl}, 0.1 \mathrm{M}$ $\mathrm{NaCl}, 20 \mathrm{mM}$ EDTA, $0.5 \mathrm{mg}$ ovalbumin/ml, pH 7.90 and $25 \mu \mathrm{l}$ of S2238 $(4 \mathrm{mM})$ prewarmed for at least $5 \mathrm{~min}$ at $37^{\circ} \mathrm{C}$. After 120 seconds the reaction in the cuvette is stopped by adding $300 \mu \mathrm{l}$ of concentrated acetic acid. The cuvettes are read at $405 \mathrm{~nm}$ in a LKB Ultrospec II spectrophotometer. The amidolytic activitics in the plasma samples were calculated from the O.D. reading and expressed as the equivalent concentration of thrombin. The generation of prothrombinase activity was calculated from the amidolytic activity curve with the aid of a computer program as described previously (1). Briefly, the observed amidolytic activity is the sum of thrombin activity and the activity of $\alpha_{2} \mathrm{M}$-thrombin complex. The rate of thrombin generation at any moment is the sum of two processes: a) the conversion of prothrombin into thrombin by prothrombinase and b) the decay of thrombin by the action of plasma protease inhibitors. The rate of inhibition of thrombin at any time can be calculated from the concentration of thrombin at that moment and the pseudo first order rate constant of inhibition of thrombin by antithrombin III $\left(\mathrm{k}_{1}\right)$ and $\alpha_{2}$-macroglobulin $\left(\mathrm{k}_{2}\right)$. The rate of prothrombin activation (prothrombinase activity) then can be calculated from the observed rate of generation of amidolytic activity and the rate of thrombin inhibition.

\section{Determination of the Pseudo First Order Rate Constant of Inhibition of Thrombin in Plasma}

Defibrinated plasma $(200 \mu \mathrm{l})$ was incubated with $24 \mu \mathrm{l}$ of buffer containing $0.05 \mathrm{M}$ Tris- $\mathrm{HCl}, 0.1 \mathrm{M} \mathrm{NaCl}, 0.5 \mathrm{mg}$ ovalbumin/ml, $\mathrm{pH} 7.35$. Thrombin generation was started as described in the previous section. Two minutes after the peak activity of thrombin, $10 \mu \mathrm{l}$ of Soybean Trypsin Inhibitor (SBTI) solution $(10 \mathrm{mg} / \mathrm{ml})$ was added, together with $16 \mu \mathrm{l}$ of buffer that contained the heparin to be tested. SBTI at this concentration was shown to stop completely and instantaneously the activity of prothrombinase and not to influence the activity of thrombin (1). At suitable time intervals after addition of the SBTI solution, $10 \mu \mathrm{l}$ aliquots of the incubation mixture were added to cuvettes to measure residual thrombin activity as described. The pseudo first order ratc constant of inhibition of thrombin generated in plasma was calculated by fitting the data to

$\mathrm{C}_{\mathrm{t}}=\mathrm{C}_{\mathrm{R}}+\mathrm{C}_{\mathrm{o}} \mathrm{e}^{-\left(\mathrm{k}_{\mathrm{t}}+\mathrm{k}_{2}\right) \mathrm{t}}$

where $C_{t}$ is the thrombin activity at time $t, C_{R}$ is the steady end-level activity, $\mathrm{C}_{\mathrm{o}}+\mathrm{C}_{\mathrm{R}}$ is the thrombin activity at the time of SBTI addition, $\mathrm{k}_{1}$ is the AT III-dependent decay constant of inhibition of thrombin, $\mathrm{k}_{2}$ is the decay constant of inhibition of thrombin by $\alpha_{2}$-macroglobulin $\left(\alpha_{2}-\mathrm{M}\right)$. The ratio of $k_{1}$ to $k_{2}$ is determined as the ratio of the amounts of thrombin complexed with AT III and $\alpha_{2}-\mathrm{M}$ as described before (1).

First order rate constants in plasma were obtained as indicated above. In purified systems they were derived from the semi-logarithmic decay of factor activity in the presence of AT III and heparin at the concentration indicated (Tables 2 and 3).

The second order rate constants were obtained from the first order rate constants by dividing through the AT III-heparin concentration prevailing in the experiments.

\section{Results}

\section{Effect on the Decay of Thrombin Generated in Plasma}

In Fig. 1 we see that with regard to their action on thrombin the low molecular weight heparins (LMWH) appear in two groups: those such as EMT 966 and PK10169 that, like standard heparin, do increase the AT III dependent breakdown constant $\left(\mathrm{k}_{1}\right)$ of endogenous thrombin and EMT 967 that does not. It is seen that there is a rectilinear relationship between the concentration of heparin and the decay constant of thrombin for EMT 966, PK10169 and standard heparin. From the slopes of these lines the second order rate constants of thrombin inactivation in PPP can be calculated (Table 2). These second order rate constants enable us to compare the antithrombin activity in plasma of different
LMW heparin on a weight basis and their relation to the activity of UFH.

In Table 2 they are also compared to the values found in a purified system consisting in AT III (400 nM), thrombin (20 nM) and heparin (varying concentrations). The rate constants of LMWH are considerably lower than those of standard heparin. This is especially clear when the results are expressed on a molar basis. The activity of heparins in plasma is about $15-35 \%$ of that observed in a purified system. This can be attributed to the lower susceptibility of endogenous thrombin to AT III(-heparin) action and/or to the presence of heparin binding proteins in plasma.

In Table 3 we summarize the data on the breakdown constants of factor $\mathrm{II}_{\mathrm{a}}, \mathrm{IX}_{\mathrm{a}}, \mathrm{X}_{\mathrm{a}}$ and $\mathrm{XI}_{\mathrm{a}}$ in purified systems. The activity of heparins decreases in the order $\mathrm{II}_{\mathrm{a}}, \mathrm{X}_{\mathrm{a}}, \mathrm{IX}_{\mathrm{a}}$ and $\mathrm{XI}_{\mathrm{a}}$. The exception is EMT 967 that has no activity towards thrombin.

In order to see whether EMT 967 competes with EMT 966 for AT III under our experimental circumstances, we added increasing amounts of EMT 967 to a fixed amount of EMT 966, it did not cause any significant change in the activity of the EMT 966 (Fig. 2).

\section{Influence of LMW Heparins on the Thrombin Generation in Plasma}

The formation of thrombin in plasma was measured in the presence and absence of PK10169, EMT 966 and EMT 967, both

Table 1 Characteristics of the heparins studied

\begin{tabular}{llll}
\hline Heparins & $\begin{array}{l}\text { Mean molecular } \\
\text { weight } \\
\text { (range) }\end{array}$ & $\begin{array}{l}\text { Anti IIa } \\
\text { activity } \\
\text { (U/mg) }\end{array}$ & $\begin{array}{l}\text { Anti Xa } \\
\text { activity } \\
\text { (U/mg) }\end{array}$ \\
\hline 4th I.S.H. & $14(3-18)$ & 194 & 194 \\
PK10169 & $4.5(2-9)$ & 30 & 120 \\
EMT 966 & $6.5(5-9)$ & 70 & 160 \\
EMT 967 & $3.3(2-4)$ & 0 & 10 \\
\hline
\end{tabular}

The anti $\mathrm{II}_{\mathrm{a}}$ and anti $\mathrm{X}_{\mathrm{a}}$ activities were estimated according to (4).

Table 2 The second order rate constants of the inactivation of thrombin for heparins

\begin{tabular}{lcllll}
\hline & \multicolumn{3}{c}{ A) $\mathrm{k}\left(\mathrm{min}^{-1} \cdot \mu \mathrm{g}^{-1} \cdot \mathrm{ml}\right)$} & $\mathrm{B}) \mathrm{k}\left(\mathrm{min}^{-1} \cdot \mathrm{nM}^{-1} \cdot \mathrm{ml}\right)$ \\
\cline { 2 - 6 } Heparin & Purified & Plasma & Purified & Plasma & $\mathrm{R}$ \\
\hline 4th I.S.H. & 38.7 & 8.57 & 542 & 120 & 4.5 \\
PK10169 & 7.3 & 1.11 & 33 & 5 & 6.5 \\
EMT 966 & 14.8 & 5.14 & 96.2 & 33 & 3 \\
EMT 967 & 0 & 0.05 & 0 & 0.16 & 0
\end{tabular}

In section $\mathrm{A}$ the data are on weight basis, in section $\mathrm{B}$ they are calculated on basis of the molar concentration, using the molecular weights from Table 1.

$\mathrm{R}=$ Ratio of the rate constant in a purified system over that in plasma

Table 3 The second order breakdown constants of various clotting proteases with heparins in a purified system

\begin{tabular}{lclll}
\hline Heparin & IIa & IXa & Xa & XIa \\
\hline 4th I.S. H. & 38.7 & 0.180 & 4.1 & 0.021 \\
PK10169 & 7.3 & 0.109 & 0.8 & 0.002 \\
EMT 966 & 14.8 & 0.158 & 1.3 & 0.006 \\
EMT 967 & 0 & 0.020 & 0.4 & 0.001 \\
\hline
\end{tabular}

$\mathrm{k}$ is expressed in $\min ^{-1} \cdot \mu \mathrm{g}^{-1} \cdot \mathrm{ml}$

Experimental conditions:

a) AT III: $400 \mathrm{nM}$; $\mathrm{II}_{\mathrm{a}}$ : $20 \mathrm{nM}$; heparin : 0-300 ng/m]

b) AT III: $400 \mathrm{nM}$; IX $: 80 \mathrm{nM}$; heparin: $0-1 \mu \mathrm{g} / \mathrm{ml}$

c) AT III: $400 \mathrm{nM} ; X_{a}: 20 \mathrm{nM}$; heparin: $0-300 \mathrm{ng} / \mathrm{m}$ ]

d) AT III: $400 \mathrm{nM}$; $\mathrm{XI}_{\mathrm{a}}: 4 \mathrm{nM}$; heparin: $0-5 \mu \mathrm{g} / \mathrm{ml}$ 


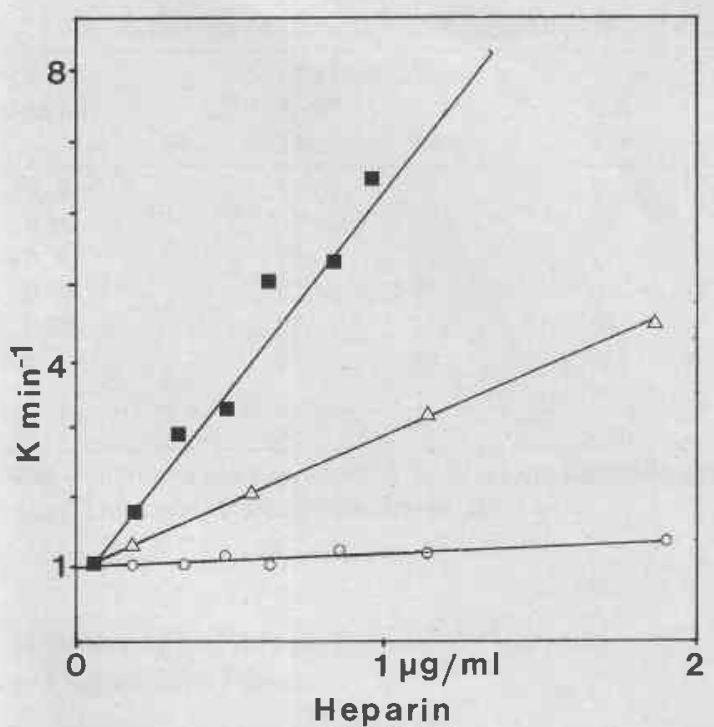

Fig. 1 The AT III-dependent pseudo first order rate constant of thrombin decay in thromboplastin activated plasma as a function of the heparin concentration. $\square$ EMT 966; $\triangle$ PK10169; O EMT 967

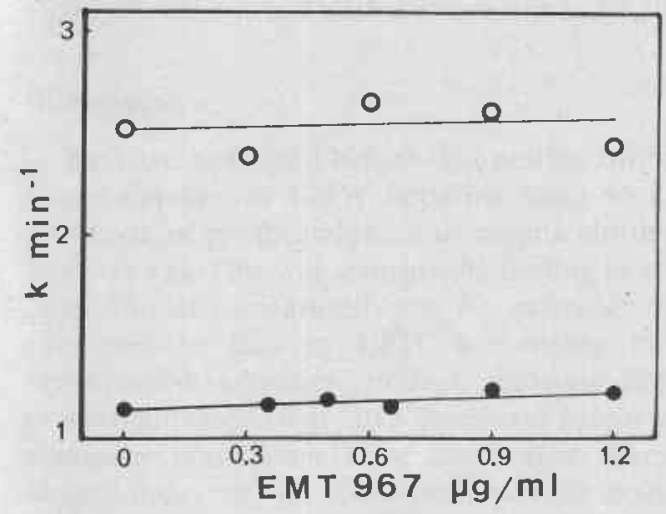

Fig. 2 Influence of the addition of increasing amounts of EMT 967 on the thrombin decay constant of a fixed concentration of EMT 966. EMT 966; $00.3 \mu \mathrm{g} / \mathrm{ml}$ EMT 966

in the extrinsic system using thromboplastin as a trigger and in the intrinsic system using kaolin and phospholipid as a trigger. Because EMT 967 is partially adsorbed onto kaolin at the usual concentration of $25 \mu \mathrm{g} / \mathrm{ml}$ of kaolin we used $2.5 \mu \mathrm{g} / \mathrm{ml}$. This still ensures normal contact activation but heparin adsorption is negligible.

As shown in Fig. 3, $0.6 \mu \mathrm{g} / \mathrm{ml}$ and $1.2 \mu \mathrm{g} / \mathrm{ml}$ of PK10169 inhibit respectively $50 \%$ and $68 \%$ of the thrombin burst via the extrinsic pathway and $40 \%$ and $58 \%$ of thrombin in intrinsic pathway.

In Fig. 4 we can see that $0.2 \mu \mathrm{g} / \mathrm{ml}$ and $0.6 \mu \mathrm{g} / \mathrm{ml}$ of EMT 966 inhibit respectively $37 \%$ and $72 \%$ in the extrinsic system and $44 \%$ and $74 \%$ in the intrinsic system. EMT 967 proves much less active. It was necessary to increase its concentration up to $5 \mu \mathrm{g} / \mathrm{ml}$ to obtain significant inhibition.

The question now arises whether the inhibition of the thrombin burst is due to inhibition of prothrombin activation or to increased thrombin decay.

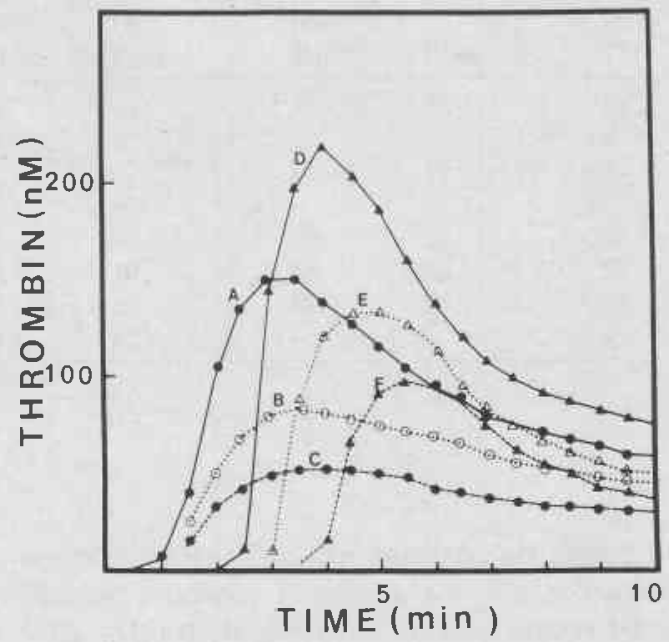

Fig. 3 The effect of PK10169 on the thrombin generation induced by thromboplastin (curves A, B, C) or by contact activation and phospholipids (curves D, E, F). A and D: no heparin; B and E: $0.6 \mu \mathrm{g} / \mathrm{ml}$; $\mathrm{C}$ and $\mathrm{F}: 1.2 \mu \mathrm{g} / \mathrm{ml}$

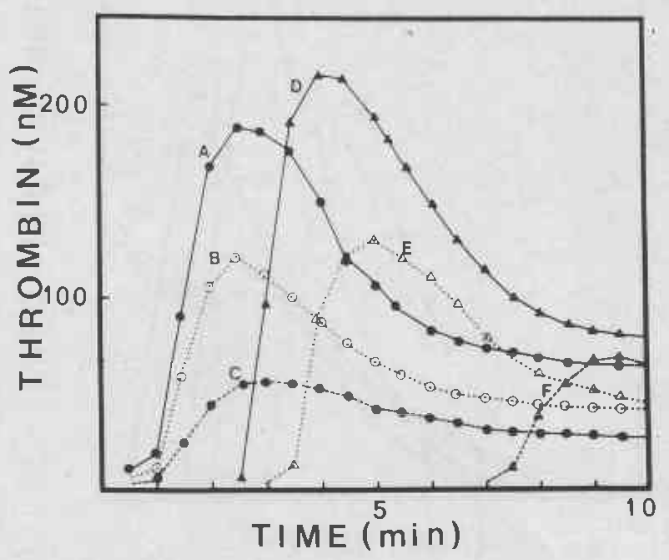

Fig. 4 The effect of EMT 966 on the thrombin generation induced by thromboplastin or by contact activation and phospholipids. Legends as in Fig. 2

\section{Influence of $L M W$ Heparins on the Prothrombinase Activity in Plasma}

Using the pseudo first order rate constants of inhibition of thrombin by antithrombin III $\left(\mathrm{k}_{1}\right)$ expressed in Fig. 1 and the value of 0.23 for the decay constant of thrombin $\left(k_{2}\right)$ due to $\alpha_{2^{-}}$ macroglobulin (1), we calculated the prothrombinase activity from the thrombin generation curves.

The data are shown in Table 4 . In the extrinsic pathway, EMT 966 causes its inhibition by thrombin scavenging without inducing an important inhibition of prothrombinase in the extrinsic system. If thus acts exactly like standard heparin (2), EMT 967 is different. Only at high concentrations it inhibits the thrombin peak, this inhibition must be attributed to the inhibition of prothrombinase or to a decreased prothrombinase generation because there is no influence on thrombin decay. PK10169 appears to inhibit by increased scavenging of thrombin as well as by prothrombinase inhibition (Table 4 , Fig. 5 ). 
Table 4 Summary of the inhibitions observed via the extrinsic and intrinsic pathways

\begin{tabular}{|c|c|c|c|c|c|c|c|c|c|c|}
\hline $\begin{array}{l}\text { Conc. } \\
(\mu \mathrm{g} / \mathrm{ml})\end{array}$ & $\begin{array}{l}\text { EMT } \\
\text { Extr. } \\
\text { Thr. }\end{array}$ & P.ase & $\begin{array}{l}\text { Intr. } \\
\text { Thr. }\end{array}$ & P.ase & $\begin{array}{l}\text { EMT } \\
\text { Extr. } \\
\text { P.ase }\end{array}$ & $\begin{array}{l}\text { Intr. } \\
\text { P.ase }\end{array}$ & $\begin{array}{l}\text { PK10 } \\
\text { Extr. } \\
\text { Thr. }\end{array}$ & P.ase & $\begin{array}{l}\text { Intr. } \\
\text { Thr. }\end{array}$ & P.ase \\
\hline 0.05 & 12 & 7 & 17 & 13 & - & - & 13 & 20 & 16 & 5 \\
\hline 0.20 & 37 & 8 & 44 & 20 & - & - & - & - & - & - \\
\hline 0.30 & 59 & 10 & - & - & - & - & 26 & 19 & 23 & 9 \\
\hline 0.35 & 62 & 12 & - & - & - & - & - & - & - & - \\
\hline 0.60 & 72 & 18 & 68 & 17 & - & - & 50 & 28 & 40 & 18 \\
\hline 1.2 & 87 & 20 & 95 & 53 & 11 & 10 & 68 & 42 & 58 & 26 \\
\hline 5 & - & - & - & - & 53 & 30 & 85 & 45 & 80 & 31 \\
\hline 10 & - & - & - & - & 81 & 62 & - & - & - & - \\
\hline
\end{tabular}

The inhibitions are expressed in \% of an uninhibited control run in parallel.

Thr.: Thrombin; P.ase: Prothrombinase.

\section{Influence of $L M W H$ on Thrombin Generation in Platelet-Rich Plasma}

In an attempt to investigate the action of our LMW heparins in a situation nearer to the in vivo circumstances we measured thrombin generation in platelet rich plasma (PRP).

As previously found for unfractionated heparin $(2,7)$ we observed that PK10169 induces a prolongation of the lag phase before the appearance of the thrombin burst. Contrary to standard heparin, PK10169 inhibits also the peak of thrombin as shown in Fig. 6. One of the subfractions of PK10169, EMT 966 has the same behaviour but EMT 967 is hardly efficient in the range of concentrations that is present in PK10169 (Fig. 6).

\section{Discussion}

We have described before that neither unfractionated heparin nor a number of LMW heparins seem to cause a significant inhibition of prothrombinase in plasma clotting via the extrinsic pathway (2). This was a surprising finding in view of the fact that conventionally measured anti $X_{a}$ activities of LMWHs, when compared to that of UFH, are higher then the respective antithrombin activities. In fact, the only LMWHs that inhibit prothrombinase activity to a significant extent without influencing thrombin breakdown were those that, like the Choay pentasaccharide, do not show antithrombin activity. We therefore proposed the existence of two classes of heparin, those active against thrombin but hardly against prothrombinase (S heparin) and those inactive against thrombin but active against prothrombinase (P heparin) $(2,3)$.

In this article we describe that PK10169, a LMWH with a mean molecular weight of 4,500 daltons does inhibit prothrombinase but also increases the AT III dependent breakdown of thrombin in plasma. This raises the question of whether there exist heparins of a mixed P \& S type. Alternatively preparations that show a mixed type behaviour may indeed be mixtures of $\mathrm{P}$ type and $S$ type molecules.

We separated PK10169 in a high $(6.5 \mathrm{kDa})$ and a lower (3 kDa) molecular weight fraction. The low molecular weight fraction (EMT 967) showed a pure P type behaviour, i.e. no thrombin inhibition but a persistent antiprothrombinase activity at relatively high concentration $(>5 \mu \mathrm{g} / \mathrm{ml})$. The higher molecular weight fraction (EMT 966) obtained the characteristics of an S type heparin, i.e. persistent antithrombin activity and low antiprothrombinase activity. It appears therefore more likely than not that the mixed type behaviour of PK10169 is due to its being a mixture of $\mathrm{P}$ and $\mathrm{S}$ type heparins. It must be noticed however, that whereas P type heparins (i.e. pentasaccharide and EMT 967) have no antithrombin activity, $S$ type heparins always have a residual antiprothrombinase activity that shows up at higher concentrations. This can partly be attributed to inhibition of the positive feedback reactions, i.e. the activation of factor $\mathrm{V}$ and VIII. Also these preparations may always be contaminated by $\mathrm{P}$ type heparins. It cannot be excluded, however, that $S$ type heparins have an inherent antiprothrombinase activity that is obscured by the far more outspoken antithrombin activity.

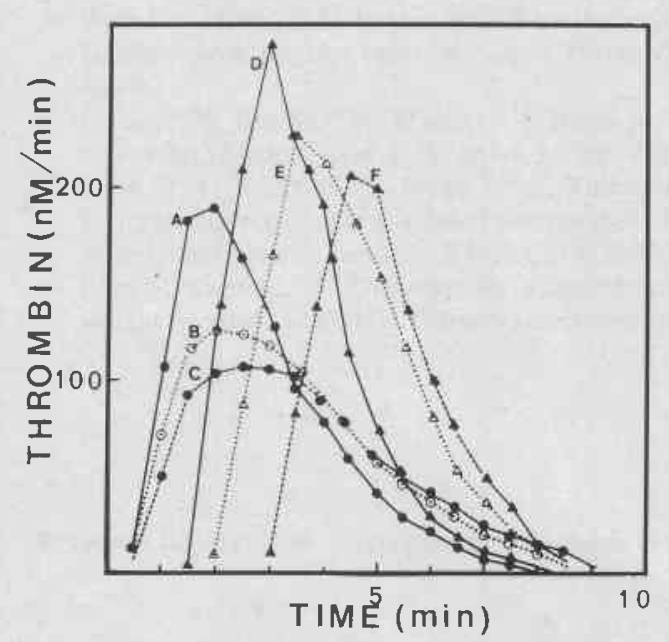

Fig. 5 The effect of PK10169 on prothrombinase activity. Prothrombinase activities, were calculated from the thrombin generation curves shown in Fig. 3. Legends as in Fig. 3

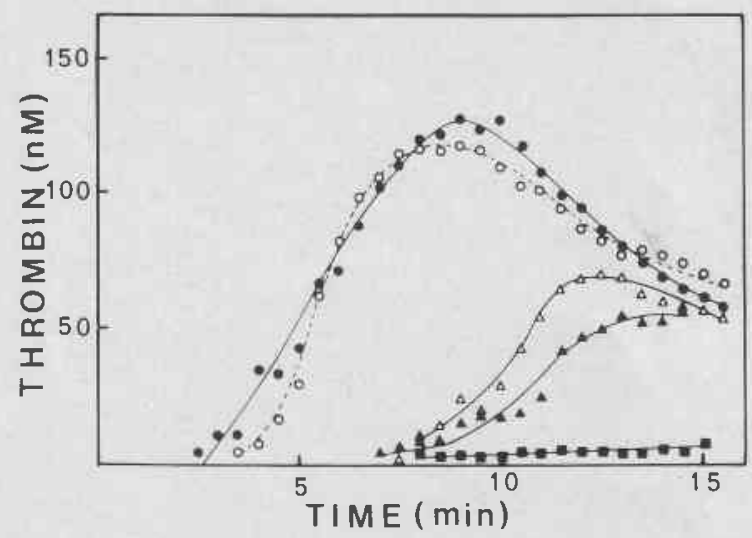

Fig. 6 Influence of EMT 966, EMT 967, recombined PK10169 on the thrombin generation in platelet rich plasma in the presence of traces of thromboplastin (1/2400 final dilution). No heparin; $\triangle 1.3 \mu \mathrm{g} / \mathrm{ml}$ EMT 966; O $0.7 \mu \mathrm{g} / \mathrm{ml}$ EMT 967; $4 \mu \mathrm{g} / \mathrm{ml}$ PK10169: $\Delta 1.3 \mu \mathrm{g} / \mathrm{ml}$ EMT $966+0.7 \mu \mathrm{g}$ EMT 967 
The differences of the mode of action of LMWHs on isolated factors, even when added back to plasma as in the conventional anti $\mathrm{II}_{\mathrm{a}}$ and anti $\mathrm{X}_{\mathrm{a}}$ tests, and on factors generating in clotting plasma remain intriguing. At the moment we cannot offer an explanation.

If in PPP, within the group of S type heparins, there is no difference in the mode of action of UFH and LMWH, an important difference appears as soon as PRP is tested. We have shown before that up to $0.5 \mathrm{U} / \mathrm{ml}$ of UFH is practically completely inactivated by activated platelets. This makes that UFH in PRP postpones the thrombin burst but hardly inhibits it (7). As we can see from Fig. 6. PK10169 and EMT 966 both postpone and inhibit the generation of thrombin in PRP. Preliminary experiments suggest that this is due to a lower suceptibility of LMWHs to $\mathrm{pf} 4$. This is in good accordance with observations showing pf4 susceptibility to decrease with decreasing molecular weight (8-12).

In Fig. 6 is seen that EMT 967, when added in a concentration of $0.7 \mu \mathrm{g} / \mathrm{ml}$ does not significantly inhibit thrombin generation in PRP. When the same amount is added to $1.4 \mu \mathrm{g} / \mathrm{ml}$ of EMT $966 \mathrm{it}$ enhances the inhibition caused by EMT 966. The likely explanation is that EMT 967 binds to pf4 and neutralizes it so that more EMT 966 is left in free form. This may be an example of a general mechanism by which LMWHs that in itself are inactive may, in PRP, potentiate the action of active heparin components.

Our results impact on the problem of standardization of heparins (13). At least three different properties of a heparin will determine its effect in vivo: a) antithrombin activity, b) antiprothrombinase activity and c) platelet factor 4 sensitivity. A priori it seems improbable that the in vivo activity of a heparin would be rendered adequately by any single in vitro test because this would require this test to be sensitive to $a, b$ and $c$ in precisely the same manner as the in vivo thrombotic and/or bleeding tendency is. Because the action of a heparin is the function of at least three variables, heparin cannot be characterized by a one dimensional value, but like for instance colour, should be characterized by a three dimensional vector. We do not know what the optimal combination of properties of a heparin is. Careful characterization of different preparations and correlation of these properties to clinical observation may eventually give the answer.

\section{References}

1 Hemker H C, Willems G M, Béguin S. A computer assisted method to obtain the prothrombin activation velocity in whole plasma independent of thrombin decay processes. Thromb Haemostas 1986; 56: 9-17.

2 Hemker H C. The mode of action of heparin in plasma. In: Thrombosis and Haemostasis 1987. XIth Congress on Thrombosis and Haemostasis, Brussels 1987. Vermylen J, Lijnen R, Arnout J (eds). pp 17-36.

3 Béguin S, Lindhout Th, Hemker H C. The mode of action of heparin in plasma. Thromb Haemostas 1988; 60: 457-62.

4 Vinazzer $H$, Woler $M$. A new low molecular weight heparin fragment (PK10169). In vitro and in vivo studies. Haemostasis 1986; 16: 106-15.

5 Thaler $\mathrm{E}$, Schmer G. A simple two stop isolation procedure for human and bovine antithrombin II/III (heparin co-factor): a comparison of two methods. Br J Haematol 1975; 31: 233-43.

6 Miller-Andersson M, Borg $\mathrm{H}$, Andersson L-O. Purification of antithrombin III affinity chromatography. Thromb Res 1974; 439-52.

7 Béguin S, Hemker H C, Lindhout Th. The effect of trace amounts of tissue factor on thrombin generation in platelet rich plasma, its inhibition by heparin. Thromb Haemostas 1989; 61: 25-9.

8 Walz D A, Ciaglowski R E, Walenga J M, Fareed J. Studies of the binding of heparin, its low molecular weight fraction and biologically active fragments with bovine and human platelet factor 4 . Thromb Haemostas 1983; 50: 183 (Abstr 0563).

9 Lane D A, Denton J, Flynn A M, Thunberg L, Lindahl U. Anticoagulant activities of heparin oligosaccharides and their neutralization by platelet factor 4. Biochem J 1984; 218: 725-32.

10 Walz D A, Hung G L. In vivo studies on the binding of heparin and its fractions with platelet factor 4. Semin Thromb Haemostas 1985; 11: $40-7$.

11 Cowan S W, Bakshi E N, Machin K J, Isaacs N W. Binding of heparin to human platelet factor 4. Biochem J 1986; 234: 485-8.

12 Lane D A, Pejler G H, Flynn A M, Thompson E A, Lindahl U. Neutralization of heparin-related saccharides by histidine-rich glycoprotein and platelet factor 4. J Biol Chem 1986; 261: 3980-6.

13 Bara L, Samama M. The need for standardization of low molecular weight heparin (LMWH). Thromb Haemostas 1986; 56: 418.

Received July 11, 1988 Accepted after revision November 13, 1988 